\title{
20. Have You Got a Title? Seminar Daze
}

The Coombs: A House of Memories (2006), pp. 235-42.

When I arrived at the Coombs Building at the end of 1972, I reported to my new head of department, John La Nauze, in the Research School of Social Sciences. An Australian who had been at Balliol College, Oxford, in the 1930s, La Nauze seemed reserved and English. 'And what are you going to do, Nelson?' he asked. I told him that I was going to write a book. I was just about to launch into a summary of the astounding soon-to-be book, when he said, 'That's good, Nelson. Some people come here and they just go to seminars or do photocopying. I'm glad you're writing a book'. With that the meeting ended and I was out in the still unfamiliar Coombs corridors. I thought, he has lived up to his name, 'Jack the Knife'. Later, I was to appreciate La Nauze's scholarship and generosity. As I should have known, his learning, craft as a writer and understanding of his fellows were all apparent in his two-volume biography of Alfred Deakin.

La Nauze was right to warn of the time-consuming danger of seminars. In an ordinary week there are about 55 seminars in the six seminar rooms of the Coombs. On Mondays there might be eight or nine; they peak on Tuesdays, Wednesdays and Thursdays in a flush mid-week harvest of a dozen-a-day seminars; and decline to nine or ten again on Fridays. In most weeks the Coombs seminars spill over into University House, where departments sponsor one-or two-day conferences, and the Chancelry, where they exploit executive meeting rooms. Before the opening of the annex, Coombs academics were holding some 65 seminars a week. That's well over 2000 in a year. During the 33 years that I have been around the Coombs, perhaps 50,000 nervous or confident, novice or experienced academics have presented seminar papers.

Seminars flourish in spite of doubtful utility. It takes longer to listen to 6000 words than to read them, and reading is more likely to lead to careful assessment. Most people going to seminars retain little. They have just a general interest in the topic, and they note details only when they are relevant to their own work. Beyond that, they might be stimulated by the scholarly method, the way material is organised, or sources of data. Two days after the seminar, they would be lucky to recall five out of 50 minutes, and in a week that might be reduced to two. The seminar survives as a social occasion, a test before peers, and a commitment to a date that forces production. The seminar paper will have a second life as an article or a chapter. 
Like others, I remember more of the occasion and particular incidents than the content. It was always good to sit alongside Bob Langdon. Bob had no formal tertiary education, but he was not intimidated by real or pretended expertise. In his own search for learning, he asked frank and searching questions, and in reply he demanded clarity. He also had a special weapon. Having gone from school to South Australian public service and in 1942 into the Australian navy, Bob worked his way to post-war England as a merchant seaman. Down and out in London, he revived his school shorthand by pawning his watch and typewriter, took a course at Pitman's College and spent his time on lightening phrases and transcribing his Concise Oxford Dictionary into shorthand. Soon his shorthand speed was fast enough to apply for a job as a Hansard reporter. Instead he went to Bolivia, and later exploited his shorthand as secretary and journalist. In Seminar Room E, Bob always listened intently, but would appear to take down just a quick casual note or two. At the end of the seminar he would preface a question with a statement such as: 'When talking about Queen Emma in Rabaul you said ...' The astonishment of many a stranger to the Coombs grew with each verbatim sentence quoted back. Suddenly, the presenter realised he might be held to account for every word.

It was different sitting next to Oskar Spate. He had come to the Department of Pacific and Southeast Asian History after a career as geographer and director of the Research School of Pacific Studies. As he listened to the speaker, he would draw a contour map. Gradually a landscape emerged: promontories, deep gullies and winding streams, the density of contours indicating steep slopes and much danger of erosion. He would also pen witty couplets and limericks. On the back of a filing card on which was typed 'Tate, Vernon, Spanish Documents relating to the Voyage of the Racoon ...' he once scribbled:

A chesty young lass of Mount Hagen

Believed in straight talk and no jargon

'I want two hundred pigs

ten shells and twelve wigs,

and even at that I'm a bargain!'

A good listener and sharp critic, Oskar sometimes made it hard for those beside him to give full attention to the speaker. I kept the card on which he had written of the Mount Hagen lass, and later used it as a bookmark in his autobiography, On the Margins of History.

Derek Freeman could be a more disconcerting seminar companion. When new to the Coombs, I went to an Anthropology Department seminar and sat next to Derek. Even before the seminar began he had taken out the Oxford 
University Press edition of The Poetical Works of William Blake, and was soon immersed in Songs of Innocence and Experience. As the speaker began, Derek turned away so that his shoulder and most of his back were towards the head of the table. Every now and again Derek demonstrated his commitment to the power and simplicity of Blake's lines by making a note in the margin. Distracted and uncomfortable at this display of apparent indifference to what was being said, I missed much of the seminar. But as soon as the chairman asked for any questions and comments, Derek put his book down, corrected a couple of points of detail in the presentation and then fluently and without rancour destroyed the basis of the paper.

In Coombs seminars, careers have been made and ended. I chaired two ends. In one, words that should have been seen to be empty in writing were obviously so when spoken. It was then clear that the speaker would never write a publishable book. On another day I chaired C. Hartley Grattan who had by then retired from the University of Texas. Grattan had first visited Australia in 1927, published his first work on Australian literature soon after, and in 1942 had written Introducing Australia, a significant book for its time and for the Americans who were to read it. In 1963 he had published his two-volume work, The Southwest Pacific. The Grattan that I ushered from the tea room to Seminar Room D had a fifty-year record of writing on Australasia, was carefully dressed, urbane, and while elderly still had an easy fluency in an accent that came from Massachusetts, Texas and much world travel. He had notes to carry him through the first part of the address, but when he had to speak from memory he lost his certainty of sentence construction, and at times wandered into endless clauses. He had the fluency but he was not conveying the scholarship that he had displayed so easily through a long career. It was very sad. In question time he recovered, and answered adequately. Afterwards one of my colleagues told me I should have stopped the presentation much earlier. I replied simply, 'I couldn't'.

In the same room and soon after, I chaired another seminar which was equally embarrassing but the cause less public and more comic. A colleague had encountered an ex-diplomat who at the height of his career had been - and I am now making up details - the Third Secretary in the High Commission in Apia where he had been witness to significant events. He was asked to come along and share his knowledge. Unfortunately I had not been able to get a clear idea of what he was going to talk about, and as we sat at the head of the table waiting for casual academics to wander in, tinkling their cups and saucers, I leaned across and said, 'Have you got a title?' 'No', he answered, with fierce enthusiasm. He then launched into an impassioned speech: 'Well might you ask. All the other members of the department have been recognised. None of them, I think I can fairly say, have my record of service. I thought that in the last Queen's Birthday List I would have been recognised'. At this point I belatedly 
realised that I had invited him to express his pent-up anger about his own lack of a title. That left both of us in need of a title. I commiserated with him, and turned to the audience and gave some lame introduction which went a little like: 'How fortunate we are to have Mr ... with us and, as we all know, he is going to talk about something or other and it probably happened in Apia or nearby ...'

One of the most tense and productive seminars that I have been involved in took place in August 1991. Gavan McCormack and I gathered together six Australian ex-prisoners of war, a Korean who had served in the Japanese army as a guard of the prisoners, Japanese historians and Australian and Japanese journalists. All the ex-servicemen had been on the Burma-Thailand Railway. Because we were uncertain about what would happen and we did not want to put excess strain on the elderly participants, we had given the seminar no more publicity than the internal reminders that normally circulated within the Coombs for a departmental seminar. We also wanted all the participants to sit around the central table and talk, rather than give formal papers to an audience on the other side of a lectern. Some of the ex-prisoners of war, such as Tom Uren, ex-cabinet minister in the Whitlam and Hawke governments, and Sir Edward 'Weary' Dunlop, already recognised as the heroic surgeon and leader, were experienced speakers, and while all the others were articulate, several were hesitant about speaking at a university at any time, and certainly before an audience including their ex-enemies. We had unwisely used the term 'colloquium' in one of the descriptions of what we hoped was to happen. Hugh Clarke, an artillery man who had worked on the Thai end of the railway and then been shipped to Japan, rang up and asked, 'What's a bloody colloquium? I can't even understand what the dictionary says'.

We wanted the ex-prisoners to be candid and detailed. They had to show what was concealed behind phrases in Japanese histories which referred to 'unfortunate' or 'regrettable' events, but did not say what they were. We need not have worried. The ex-prisoners were determined to say exactly what had happened. Tom Morris had enlisted under-age straight from finishing his New South Wales Leaving Certificate, and he was nineteen when he was working on the Burma end of the Railway. Having recovered from sickness, Tom volunteered to work in the 55 Kilo Hospital, and at great emotional cost to himself he now carefully, almost relentlessly, described the stench, the overcrowding and the 'putrid cloths that were washed over and over again to cover ulcers'. The only treatment available was crude curettage of the festering ulcers, done without any pain killers or sedatives. Tom said: 'It was not unusual for 80 to 100 patients to have their ulcers scraped and gouged ... each day. It was pathetic to hear the screams of these poor souls, whose shattered nerves could no longer stand the strain ...' The nearby Japanese hospital, Tom said, was then 'lavishly supplied with drugs and medicines'. The ex-prisoners answered questions from the 
Japanese historians and journalists without any apparent anger or resentment, and again with evocative, disturbing detail. On that cold day on the shady side of the Coombs I sweated with the tension and out of sympathy for those suffering from heat and deprivation on the Railway.

The Korean ex-guard, Yi Hak-Nae, was in an invidious position. But as we learnt, much of his life had been spent in difficult circumstance, and the discomfort of speaking in a Coombs seminar in front of his victims' comrades was far from the worst situation he had faced. He too had a story that he wanted told. With single-minded concentration that seemed to add to the narrative, Gavan translated for Yi Hak-Nae. He wanted, he said, to apologise to the ex-prisoners. He had visited the graves of the 6000 prisoners buried at Kanchanaburi in Thailand, left flowers, prayed and was unable to restrain his anger and tears. He then went on to explain how he had been taken into the Japanese army, beaten every day, and sent to Thailand as a guard. There, he could not avoid 'absolute, unconditional and immediate obedience' to all orders. After the war he had been charged as a war criminal for not providing adequate food and medicines, forcing sick prisoners to work, and failing to control subordinates who illtreated prisoners. He was sentenced to death, and after eight months' wait, his sentence was reduced to twenty years imprisonment. Released on parole after ten years, he could not return to his 'beloved home country' because he was branded a Japanese collaborator and war criminal, but in Japan he had suffered discrimination and been forced to 'live in the extreme poverty'. He had been trying to persuade the Japanese government to recognise that he and his Korean comrades had been compelled to work for the Japanese army, and that they should be given the same aid that the Japanese government has given its own ex-servicemen - including those convicted of war crimes. Yi Hak-Nae also wondered why those at 'the lowest levels' went to prison and so few of those responsible for that 'nightmare period' were punished by the Allies. The exprisoners, still with vivid memories of bashings and deaths, may not have been moved to sympathy, but they did emerge with greater understanding.

The book that came out of that seminar, The Burma-Thailand Railway, was published in English and Japanese, and remained available ten years later. The Japanese scholars engaged by Gavan used their access to living and archival sources in Australia to increase their knowledge and publish further material in Japan. It was interesting to see the trust that developed between the Japanese historians and the ex-prisoners: both sides recognised the mutual desire to get the record straight. On return to Japan, one of the Japanese historians received a death threat from an extreme right wing organisation.

Nearly every week, scholars give seminars in the Coombs in what for them is a foreign language. They win admiration for battling through a written script, struggling with the inconsistencies between English spelling and pronunciation, 
and trying to interpret questions that come in a variety of accents from the Mallee and Maine to Manchester. On one occasion a speaker came to a halt, went red in the face and then emitted a word, a cough or sneeze. He went back to the start of the sentence and again halted and exploded. He tried a third time with the same result. Fortunately, a quiet, humane scholar sitting nearby looked across at the paper and said quietly, 'gonorrhoea'. The speaker had been attempting to begin a list of introduced diseases, and had been ambushed by an impenetrable collection of consonants.

My own experience of giving seminars overseas has scarcely been marked with success. When I spoke at the Cenderawasih University at Jayapura in what was then Irian Jaya, I was pleased to see a crowded hall. At the end of the talk I was given prolonged applause. For a moment I thought I had gained an international reputation. But the presence of uniformed Indonesian soldiers with pistols obvious in holsters should have alerted me to another explanation. The soldiers had rounded up the crowd to fill the hall, many of whom were neither students nor academic staff, few knew English, the language in which I had spoken, and of course they had expressed their pleasure when I had finished - they were at last going to be set free.

What makes a good seminar is elusive. An elderly actor, asked to say what separated the exceptional actor from the good and ordinary, said he had no idea, but when some actors walked on stage an audience looked, listened, and was provoked to feel and think. It is similar with seminar givers. Some scholars begin to talk and the audience listens: if others were presenting the same material the audience would think about whether they should buy bread on the way home - or mentally or actually begin to write their own next presentation. Those who have given the best seminars that I have heard (among the historians that includes Gavan Daws, Donald Denoon, Ken Inglis and Bill Gammage) spoke without rhetorical flourishes and they used plain English with a sparkling clarity, sometimes investing simple words with grace and power, and they shifted easily between particular cases, shrewd insights and generalisations. They were also saying something significant, evidenced by the prizes given to their subsequent books and the many translations of Daws' work. (Both Inglis and Gammage won Premier's Prizes and Holy Man appeared in seven languages.)

It has intrigued me that two of my colleagues can on different days give either a good or mediocre seminar. But most of us probably operate at around about the same level every time. This was brought home to me early in my career when I asked my wife if she was going to hear me give a seminar paper. She said, kindly, 'No. I have heard you'. I think that it is probably true that while I might talk about different people in different places on different events, I always give the same seminar. My wife now says that I either misheard or misinterpreted what she said, and my misunderstanding of that distant conversation comes out of 
my repetition of the anecdote, not from her words. The raises such complex questions about memory and narrative, indeed about all oral history and autobiography, that it is worthy of a seminar - even in Seminar Room A. 
This text taken from The Boy from Boort: Remembering Hank Nelson, Edited by Bill Gammage, Brij V. Lal, Gavan Daws, published 2014 by ANU Press, The Australian National University, Canberra, Australia. 